\title{
Brain volume in chronic ketamine users - relationship to sub-threshold psychotic symptoms and relevance to schizophrenia
}

\author{
Robert A. Chesters ${ }^{1,2} \cdot$ Fiona Pepper $^{1,2} \cdot$ Celia Morgan $^{3} \cdot$ Jonathan D. Cooper ${ }^{1,2,4}$. Oliver D. Howes ${ }^{1,2,5,6}$. \\ Anthony C. Vernon ${ }^{1,2,6}$. James M. Stone $e^{1,2,5,7,8}$
}

Received: 11 November 2020 / Accepted: 5 May 2021 / Published online: 6 July 2021

(c) The Author(s) 2021, corrected publication 2022

\begin{abstract}
Rationale Ketamine may model aspects of schizophrenia arising through NMDA receptor activity deficits. Although acute ketamine can induce effects resembling both positive and negative psychotic symptoms, chronic use may be a closer model of idiopathic psychosis.

Objectives We tested the hypotheses that ketamine users had lower brain volumes, as measured using MRI, and greater sub-threshold psychotic symptoms relative to a poly-drug user control group.

Methods Ketamine users $(n=17)$ and poly-drug using controls $(n=19)$ were included in the study. All underwent volumetric MRI imaging and measurement of sub-threshold psychotic symptoms using the Comprehensive Assessment of At-Risk Mental State (CAARMS). Freesurfer was used to analyse differences in regional brain volume, cortical surface area and thickness between ketamine users and controls. The relationship between CAARMS ratings and brain volume was also investigated in ketamine users.

Results Ketamine users were found to have significantly lower grey matter volumes of the nucleus accumbens, caudate nucleus, cerebellum and total cortex (FDR $\mathrm{p}<0.05$; Cohen's $\mathrm{d}=0.36-0.75$ ). Within the cortex, ketamine users had significantly lower grey matter volumes within the frontal, temporal and parietal cortices (Cohen's d 0.7-1.31; FDR $p<0.05$ ). They also had significantly higher sub-threshold psychotic symptoms $(\mathrm{p}<0.05)$. Frequency of ketamine use showed an inverse correlation with cerebellar volume $(\mathrm{p}<0.001)$, but there was no relationship between regional brain volumes and sub-threshold psychotic symptoms.
\end{abstract}

Conclusions Chronic ketamine use may cause lower grey matter volumes as well as inducing sub-threshold psychotic symptoms, although these likely arise through distinct mechanisms.

Keywords Ketamine $\cdot$ Brain volume $\cdot$ MRI $\cdot$ Schizophrenia $\cdot$ Psychosis

Anthony C. Vernon and James M. Stone shared senior authorship.

James M. Stone

j.stone@bsms.ac.uk

1 Institute of Psychiatry, Psychology and Neuroscience, King's College London, London, UK

2 Department of Basic and Clinical Neuroscience, Maurice Wohl Clinical Neuroscience Institute, London SE5 8AF, UK

3 University of Exeter, Exeter, UK

4 Departments of Pediatrics, Genetics and Neurology, Medical School, Washington University in St Louis, 660S Euclid Ave, St Louis, MO 63110, USA
5 South London and Maudsley NHS Trust, London SE5 8AZ, UK

6 MRC Centre for Neurodevelopmental Disorders, King's College London, London SE1 1UL, UK

7 Department of Neuroscience, Brighton and Sussex Medical School, University of Sussex, Falmer BN1 9RY, UK

8 Sussex Partnership NHS Foundation Trust, Eastbourne BN21 2UD, UK 


\section{Introduction}

There has been considerable interest in the role of $\mathrm{N}$-methyl-D-aspartate (NMDA) receptor dysfunction in schizophrenia. This idea originally arose through the observation that NMDA receptor antagonists such as phencyclidine (PCP) and ketamine induced psychosislike effects resembling both the positive and negative symptoms of schizophrenia (Javitt 2007; Krystal et al. 1994). Subsequent work highlighted the finding that NMDA receptor antagonists led to neurotoxic changes in rodents, which was suggested to resemble volume reductions seen in patients with schizophrenia and which was blocked by AMPA receptor antagonists, suggesting that these changes were driven, in part, by increased synaptic glutamate release (Olney and Farber 1995). Since then, there has been some evidence that NMDA receptor dysfunction might be present in patients with schizophrenia including post-mortem findings of reduced NMDA receptor mRNA in frontal cortex (Sokolov 1998), temporal cortex (Humphries et al. 1996) and hippocampus (Law and Deakin 2001) and reductions in in vivo hippocampal NMDA receptor binding in unmedicated patients with schizophrenia (Pilowsky et al. 2006).

It has been suggested that ketamine administration might model some of the features of schizophrenia, with the acute effects of ketamine resembling those seen in the prodrome of psychosis (Abi-Saab et al. 1998; Corlett et al. 2007) and exacerbating psychotic symptoms in patients with existing schizophrenia (Lahti et al. 2001; Malhotra et al. 1997). On the other hand, chronic ketamine and PCP users have been reported to have symptoms more closely resembling established schizophrenia, including paranoid delusions, auditory hallucinations and cognitive deficits (Abi-Saab et al. 1998; Javitt 2007; Jentsch and Roth 1999; Krystal et al. 1994; Morgan et al. 2012).

Brain volume reductions in frontal and temporal cortices have been reported in the transition between at risk mental state and first episode psychosis (Chung and Cannon 2015) and further reductions in frontal, parietal and temporal cortices have been reported in first episode and chronic schizophrenia (Vita et al. 2012). If chronic ketamine use is a model for schizophrenia, it might be predicted that, as well as having psychosis-like symptoms, these individuals would show a similar pattern of brain volume loss to patients with schizophrenia. Hence, one key question is whether chronic ketamine use is associated with lower brain volume compared to healthy volunteers. Our current understanding of the effects of ketamine on the brain structure is, however, poor. To the best of our knowledge, there have been three published studies reporting brain volume differences in chronic ketamine users relative to controls, the first finding lower frontal cortical volume (Liao et al. 2011), the second finding lower grey and white matter volumes in frontal, parietal, occipital and cerebellar cortices (Wang et al. 2013), and the most recent study finding lower parietal and frontal cortex grey matter volumes (Hung et al. 2020). However, these studies used non-drug using controls, and where reported, the control groups had much lower alcohol and tobacco use (Liao et al. 2011), and so the findings may have been due, at least in part, to other substances that the ketamine users may have been taking. Furthermore, none of the studies reported the relationship between brain volume and psychosis-like symptoms in the ketamine users so it is unclear if volumetric differences are linked to the clinical effects of chronic ketamine use.

To address this question, in the current study, we test the hypothesis that chronic ketamine users have reduced subcortical and cortical grey matter volume and increased levels of sub-threshold psychotic symptoms and that the cortical brain volume changes are correlated with the degree of symptom intensity.

\section{Methods}

This study utilises previously unreported volumetric MRI data acquired as part of other published studies from our group (Freeman et al. 2013; Morgan et al. 2014; Stone et al. 2014).

Thirty-six participants were recruited from a database of existing drug users at the clinical psychopharmacology unit, University College London (UCL) and via word of mouth. After giving informed consent, all participants were required to provide a self-report of their drug use history. Exclusion criteria included history of self-reported mental illness requiring psychiatric input, history of head injury, left-handedness and non-fluency in English. Seventeen ketamine users (with ketamine use at least three times per week for the past year) and 19 poly-drug using controls (with no history of regular ketamine use) were recruited through advertising and word of mouth. Participants were required to abstain from psychotropic drugs for at least $24 \mathrm{~h}$ before the study. Abstinence from recent drug use was confirmed with urine dipstick analysis. The study was approved by both the Imperial College Research Ethics Committee and the UCL Graduate School ethics committee. All participants were compensated for their time and travel expenses.

\section{Assessment of sub-threshold psychotic symptoms}

All participants were assessed for sub-threshold psychotic symptoms using the Comprehensive Assessment of At-Risk Mental State (CAARMS), a semi-structured assessment tool used to identify individuals at high risk of developing 
psychosis (Yung et al. 2005), and for schizotypal symptoms using the Schizotypal Personality Questionnaire (SPQ), a self-report scale of schizotypy (Raine 1991).

\section{Structural MRI acquisition}

MRI imaging on a Philips 3-T Intera magnetic resonance system, software release 2.1.3., was then completed. An initial localiser scan was performed followed by acquisition of a whole-brain 3D-MPRAGE (TR $=9.6 \mathrm{~ms}, \mathrm{TE}=4.5 \mathrm{~ms}$, flip angle $8^{\circ}$, slice thickness $=1.2 \mathrm{~mm}, 0.94 \mathrm{~mm} \times 0.94 \mathrm{~mm}$ in plane resolution, 150 slices).

\section{Regional brain volume analysis}

A region of interest (ROI)-based method of cortical reconstruction and volumetric segmentation was performed using the Freesurfer image analysis suite (Freeman et al. 2013), which is documented and freely available for download online (http://surfer.nmr.mgh.harvard.edu/). This processing includes motion correction and averaging of T1-weighted images to remove acquisition artefacts and removal of nonbrain tissue using a hybrid watershed/surface deformation procedure followed by automated Talairach transformation to align each MR image to a reference image before segmenting the subcortical white matter and deep grey matter volumetric structures into regions of interest. Intensity normalisation was then performed to improve the signal-noise ratio followed by computer-defined delineation of the cortical grey matter/white matter boundary and grey matter/cerebrospinal fluid border. The cerebral cortex was automatically parcellated according to the Desikan-Killiany regions of interest (Desikan et al. 2006). Cortical grey matter volume, cortical thickness, cortical surface area, subcortical white matter volume and deep grey matter volume ROI measurements were calculated.

\section{Statistical analysis}

Multivariate general linear model (GLM) statistics were performed using IBM SPSS statistics 22 to determine grouplevel differences in individual cortical ROI volumes, ROI thickness and surface area measurements, as well as cortical volume (as a whole) and subcortical grey and white matter volume. Total intracranial volume (TIV) was used as a covariate in statistical modelling of volume differences. Mathworks MATLAB R2014a was used for false discovery rate $(\mathrm{FDR})$ correction $(\mathrm{q}<0.05)$ of multiple comparisons (Genovese et al., 2002; Glickman et al., 2014). Uncorrected partial correlations were performed in IBM SPSS statistics 22 to investigate potential associations between sub-threshold psychotic symptoms and level of ketamine use with the volume of the nucleus accumbens, caudate nucleus, cerebral cortex and cerebellar cortex, within ketamine users only.

\section{Results}

\section{Demographics}

Ketamine users did not differ significantly from poly-drug using controls in terms of age, sex or years in education (Table 1). They also did not differ from controls in terms of whether they used alcohol, tobacco or cannabis but were significantly more likely to be users of 3,4-methylenedioxymethamphetamine (MDMA, 'ecstasy'), cocaine, amphetamine and heroin. Furthermore, they used alcohol, MDMA and cannabis more frequently and had a longer history of use of all substances, with the exclusion of heroin (Table 1). Ketamine users had significantly higher levels of sub-threshold psychotic symptoms, as measured by the CAARMS, and higher levels of schizotypal features on the SPQ than poly-drug using controls (Table 2). Three of the ketamine users reached criteria for psychosis, based on severity and frequency of their experiences as measured using the CAARMS.

\section{Global and regional brain volume measurements}

Freesurfer-based analysis of the apparent volumes of gross cerebral structures revealed that ketamine users had statistically significantly smaller volumes of the whole cerebral cortex, cerebellar cortex, nucleus accumbens and caudate nucleus (all FDR $p<0.05$; Cohen's d 0.36-0.75; Table 3). By contrast, the volumes of the pallidum, putamen, corpus callosum, thalamus, cerebellar white matter, amygdala, hippocampus and total cerebral white matter did not differ significantly between the groups. When excluding the 3 ketamine users who reached criteria for psychosis, the difference in total cerebral cortex volume no longer reached statistical significance (FDR $p=0.051$ ), but otherwise the findings were unchanged. To explore the cortical volume changes in more detail, we next carried out a detailed region of interest analysis of cortical regions using the 34 pre-parcellated cortical ROIs available in Freesurfer. This revealed that ketamine users had statistically significantly smaller grey matter volumes of the frontal cortex (caudal middle frontal gyrus, superior frontal gyrus and paracentral gyrus), temporal cortex (temporal pole, superior temporal gyrus, middle temporal gyrus and banks of the superior temporal sulcus) and parietal cortex (inferior parietal cortex, supramarginal gyrus and isthmus of cingulate cortex) (FDR $\mathrm{p}<0.05$; Cohen's d 0.7-1.31; Table 4). When excluding the 3 ketamine users who reached criteria for psychosis, lower grey matter volumes in caudal middle frontal gyrus, 
Table 1 Demographics and drug use in ketamine users and poly-drug using controls

\begin{tabular}{|c|c|c|c|c|}
\hline & $\begin{array}{l}\text { Poly-drug con- } \\
\text { trols }(n=19)\end{array}$ & $\begin{array}{l}\text { Ketamine } \\
\text { users }(n=17)\end{array}$ & Test statistic & p-value \\
\hline Age (mean (SD)) & $25.5(4.9)$ & $28.7(5.1)$ & $\mathrm{t}=1.9$ & 0.07 \\
\hline Sex (male/female) & $13 / 6$ & $12 / 5$ & $\chi^{2}=0.02$ & 0.9 \\
\hline Years in education (mean (SD)) & $16.8(3.6)$ & $14.6(3.5)$ & $\mathrm{t}=1.9$ & 0.07 \\
\hline \multicolumn{5}{|l|}{ Ketamine use } \\
\hline Number of regular users & 0 & 17 & - & \\
\hline Amount used (g/session) (mean (SD)) & $0.08(0.23)$ & $4(3.4)$ & $\mathrm{t}=4.66$ & $<0.001$ \\
\hline Frequency (days per month) (mean (SD)) & $0.004(0.02)$ & $17.4(11.1)$ & $\mathrm{t}=6.82$ & $<0.001$ \\
\hline Years of use (mean (SD)) & $0.1(0.3)$ & $10.5(2.7)$ & $\mathrm{t}=16.8$ & $<0.001$ \\
\hline \multicolumn{5}{|l|}{ Other drugs used } \\
\hline Alcohol & 19 & 17 & - & 1 \\
\hline Tobacco (cigarette smoking) & 8 & 9 & $\chi^{2}=1.84$ & 0.4 \\
\hline Cannabis & 17 & 17 & $\chi^{2}=1.9$ & 0.2 \\
\hline MDMA & 9 & 17 & $\chi^{2}=12.4$ & $<0.001$ \\
\hline Cocaine & 9 & 16 & $\chi^{2}=12.9$ & 0.002 \\
\hline Amphetamine & 5 & 16 & $\chi^{2}=20.7$ & $<0.001$ \\
\hline Heroin & 0 & 6 & $\chi^{2}=11.49$ & 0.003 \\
\hline \multicolumn{5}{|l|}{ Drug use (times per month) } \\
\hline Alcohol (mean (SD)) & $7.2(5.3)$ & $13.3(10.7)$ & $\mathrm{t}=2.131$ & 0.04 \\
\hline Tobacco (mean (SD)) & $11.7(12.5)$ & $17.4(14.6)$ & $\mathrm{t}=1.25$ & 0.2 \\
\hline Cannabis (mean (SD)) & $3.6(8.2)$ & $16.7(13.8)$ & $\mathrm{t}=3.47$ & 0.002 \\
\hline MDMA (mean (SD)) & $0.2(0.5)$ & $1.08(1.3)$ & $t=2.67$ & 0.01 \\
\hline Cocaine (mean (SD)) & $0.7(2.3)$ & $2.17(3.0)$ & $t=1.66$ & 0.1 \\
\hline Amphetamine (mean (SD)) & $0.0(0)$ & $4.4(10.0)$ & $\mathrm{t}=1.79$ & 0.09 \\
\hline Heroin $($ mean $\pm S D)$ & $0.0(0)$ & $0.4(0.9)$ & $\mathrm{t}=1.74$ & 0.1 \\
\hline \multicolumn{5}{|l|}{ Drug use (years of use) } \\
\hline Alcohol (mean (SD)) & $10.1(6.1)$ & $14.6(6.3)$ & $\mathrm{t}=2.16$ & 0.04 \\
\hline Tobacco (mean (SD)) & $5.6(7.0)$ & $12.8(7.4)$ & $\mathrm{t}=2.99$ & 0.005 \\
\hline Cannabis (mean (SD)) & $3.6(4.1)$ & $12.9(6.2)$ & $\mathrm{t}=5.32$ & $<0.001$ \\
\hline MDMA (mean (SD)) & $1.4(2.5)$ & $9.4(5.1)$ & $\mathrm{t}=6.03$ & $<0.001$ \\
\hline Cocaine (mean (SD)) & $1.6(2.8)$ & $7.4(4.1)$ & $\mathrm{t}=4.94$ & $<0.001$ \\
\hline Amphetamine (mean (SD)) & $0.3(0.9)$ & $8.1(6.7)$ & $\mathrm{t}=5.08$ & $<0.001$ \\
\hline Heroin (mean (SD)) & $0(0)$ & $1.8(4.2)$ & $\mathrm{t}=1.83$ & 0.076 \\
\hline
\end{tabular}

paracentral gyrus, temporal pole, inferior parietal cortex and supramarginal gyrus of ketamine users compared to controls remained statistically significant (FDR $\mathrm{p}<0.05$ ). In this post-hoc analysis, the volumes of the remaining ROIs were no longer statistically significant between the groups (all $\mathrm{p}<0.1$ ).

Ketamine users were also found to have a smaller surface area of the temporal pole and inferior parietal cortex (FDR $\mathrm{p}<0.05)$. There were no regional differences in cortical thickness between the groups that survived FDR correction.

\section{Associations between ketamine use, sub-threshold psychotic symptoms and brain volumes}

Within the ketamine user group, the frequency of ketamine use inversely correlated with the volumes of the cerebellar cortex $(r=-0.816 ; p<0.001 ;$ Fig. 1). This remained significant after correcting for multiple comparisons, including all other drug, tobacco and alcohol use as covariants $(r=-0.756 ; p<0.05)$. By contrast, there were no statistically significant relationships between ketamine use and the volumes of any other brain ROI, including cortical regions, nor between sub-threshold psychotic symptoms (assessed using CAARMS) or SPQ scores and the volumes of any brain ROI in ketamine users. There was no correlation between brain volumes and level of use for any of the other drugs of abuse in ketamine users or in poly-drug using controls.

\section{Discussion}

In this study, we found that chronic ketamine users had significantly lower grey matter volumes in the frontal, temporal and parietal cortices. These data are consistent with reports 
Table 2 Levels of subthreshold psychotic symptoms, as measured using the Comprehensive Assessment of At-Risk Mental State (CAARMS), and schizotypal features, as measured using the Schizotypal Personality Questionnaire (SPQ), in ketamine users and poly-drug using controls

\begin{tabular}{|c|c|c|c|c|}
\hline & $\begin{array}{l}\text { Poly-drug } \\
\text { controls } \\
(n=19)\end{array}$ & $\begin{array}{l}\text { Ketamine } \\
\text { users } \\
(\mathrm{n}=17)\end{array}$ & Test statistic & p-value \\
\hline \multicolumn{5}{|l|}{ CAARMS severity } \\
\hline Abnormalities of thought content $($ mean \pm SD) & $0.4 \pm 19$ & $2.5 \pm 2$ & $\mathrm{t}=4.2$ & $<0.001$ \\
\hline Abnormal perceptions $($ mean \pm SD) & $1.6 \pm 1.8$ & $3.0 \pm 1.8$ & $\mathrm{t}=2.4$ & 0.02 \\
\hline Abnormalities of speech production $($ mean $\pm \mathrm{SD})$ & $1.1 \pm 1.5$ & $2.2 \pm 1.8$ & $\mathrm{t}=1.9$ & 0.06 \\
\hline \multicolumn{5}{|l|}{ CAARMS frequency } \\
\hline Abnormalities of thought content $($ mean \pm SD) & $0.2 \pm 0.5$ & $2.6 \pm 2.2$ & $\mathrm{t}=4.5$ & $<0.001$ \\
\hline Abnormal perceptions (mean $\pm \mathrm{SD}$ ) & $0.7 \pm 1.4$ & $2.6 \pm 1.8$ & $\mathrm{t}=3.5$ & 0.001 \\
\hline Abnormalities of speech production (mean \pm SD) & $0.6 \pm 1.5$ & $2.8 \pm 2.0$ & $\mathrm{t}=3.4$ & 0.002 \\
\hline \multicolumn{5}{|l|}{ SPQ } \\
\hline Total score $($ mean $\pm \mathrm{SD})$ & $11.0 \pm 7.3$ & $27.6 \pm 20.6$ & $\mathrm{t}=3.2$ & 0.003 \\
\hline Cognitive and perceptual $($ mean \pm SD) & $2.6 \pm 2.8$ & $9.1 \pm 8.4$ & $\mathrm{t}=3.1$ & 0.004 \\
\hline Interpersonal $($ mean $\pm \mathrm{SD})$ & $4.2 \pm 3.2$ & $9.7 \pm 9.0$ & $\mathrm{t}=2.5$ & 0.018 \\
\hline Disorganisation $($ mean $\pm \mathrm{SD})$ & $3.8 \pm 4.8$ & $8.7 \pm 5.2$ & $\mathrm{t}=2.8$ & 0.008 \\
\hline
\end{tabular}

Table 3 Gross brain structures showing significant (FDR-controlled $p<0.05$ ) differences in brain volume between ketamine users and poly-drug using controls

\begin{tabular}{|c|c|c|c|c|c|c|c|c|c|}
\hline \multirow[b]{2}{*}{ Structure } & \multicolumn{2}{|c|}{ Poly-drug controls } & \multicolumn{2}{|c|}{ Ketamine users } & \multirow[b]{2}{*}{ F-statistic } & \multirow[b]{2}{*}{ p-value } & \multirow[b]{2}{*}{ q-value } & \multirow[b]{2}{*}{$\begin{array}{l}\text { Difference in } \\
\text { volume }(\%)\end{array}$} & \multirow[b]{2}{*}{ Cohen's d } \\
\hline & Mean $\left(\mathrm{cm}^{3}\right)$ & SEM & Mean $\left(\mathrm{cm}^{3}\right)$ & SEM & & & & & \\
\hline Accumbens & 1.29 & 0.03 & 1.14 & 0.03 & 10.74 & $<0.001$ & $<0.001$ & -11.64 & 0.79 \\
\hline Caudate & 8.07 & 0.19 & 7.34 & 0.20 & 7.31 & 0.01 & 0.03 & -9.05 & 0.54 \\
\hline Cerebellum & 131.01 & 2.26 & 121.95 & 2.39 & 7.52 & 0.01 & 0.03 & -6.92 & 0.56 \\
\hline Cerebral cortex & 572.91 & 8.19 & 540.95 & 8.66 & 7.14 & 0.01 & 0.03 & -5.58 & 0.36 \\
\hline
\end{tabular}

Table 4 Cortical regions showing significant (FDR-controlled $p<0.05)$ differences in brain volume between ketamine users and poly-drug using controls

\begin{tabular}{|c|c|c|c|c|c|c|c|c|c|}
\hline \multirow[b]{2}{*}{ Region of interest } & \multicolumn{2}{|c|}{ Poly-drug controls } & \multicolumn{2}{|c|}{ Ketamine users } & \multirow[b]{2}{*}{ F-statistic } & \multirow[b]{2}{*}{ p-value } & \multirow[b]{2}{*}{ q-value } & \multirow[b]{2}{*}{$\begin{array}{l}\text { Difference in } \\
\text { volume }(\%)\end{array}$} & \multirow[b]{2}{*}{ Cohen's d } \\
\hline & Mean $\left(\mathrm{cm}^{3}\right)$ & SEM & Mean $\left(\mathrm{cm}^{3}\right)$ & SEM & & & & & \\
\hline Inferior parietal cortex & 31.73 & 0.71 & 27.67 & 0.75 & 15.32 & $<0.001$ & $<0.001$ & -12.8 & 1.31 \\
\hline Temporal pole & 5.08 & 0.11 & 4.55 & 0.11 & 11.52 & $<0.001$ & $<0.001$ & -10.51 & 1.13 \\
\hline Caudal middle frontal gyrus & 16.19 & 0.55 & 13.78 & 0.58 & 9.06 & $<0.001$ & $<0.001$ & -14.89 & 1.01 \\
\hline Supramarginal gyrus & 25.43 & 0.55 & 23.21 & 0.58 & 7.68 & 0.01 & $<0.001$ & -8.74 & 0.92 \\
\hline Paracentral gyrus & 8.02 & 0.17 & 7.38 & 0.18 & 7.11 & 0.01 & $<0.001$ & -8.08 & 0.88 \\
\hline Middle temporal gyrus & 26.02 & 0.56 & 24.06 & 0.59 & 5.81 & 0.02 & $<0.001$ & -7.55 & 0.81 \\
\hline Superior frontal gyrus & 52.08 & 1.06 & 48.34 & 1.13 & 5.80 & 0.02 & $<0.001$ & -7.18 & 0.81 \\
\hline Isthmus of cingulate cortex & 5.31 & 0.14 & 4.84 & 0.15 & 5.34 & 0.03 & $<0.001$ & -8.87 & 0.77 \\
\hline Superior temporal gyrus & 27.02 & 0.62 & 25.03 & 0.65 & 4.89 & 0.03 & $<0.001$ & -7.37 & 0.74 \\
\hline Banks of superior temporal sulcus & 6.18 & 0.22 & 5.51 & 0.23 & 4.46 & 0.04 & $<0.001$ & -10.92 & 0.70 \\
\hline
\end{tabular}


Fig. 1 Partial correlation between ketamine use per month and cerebellar volume (corrected for total intracranial volume)

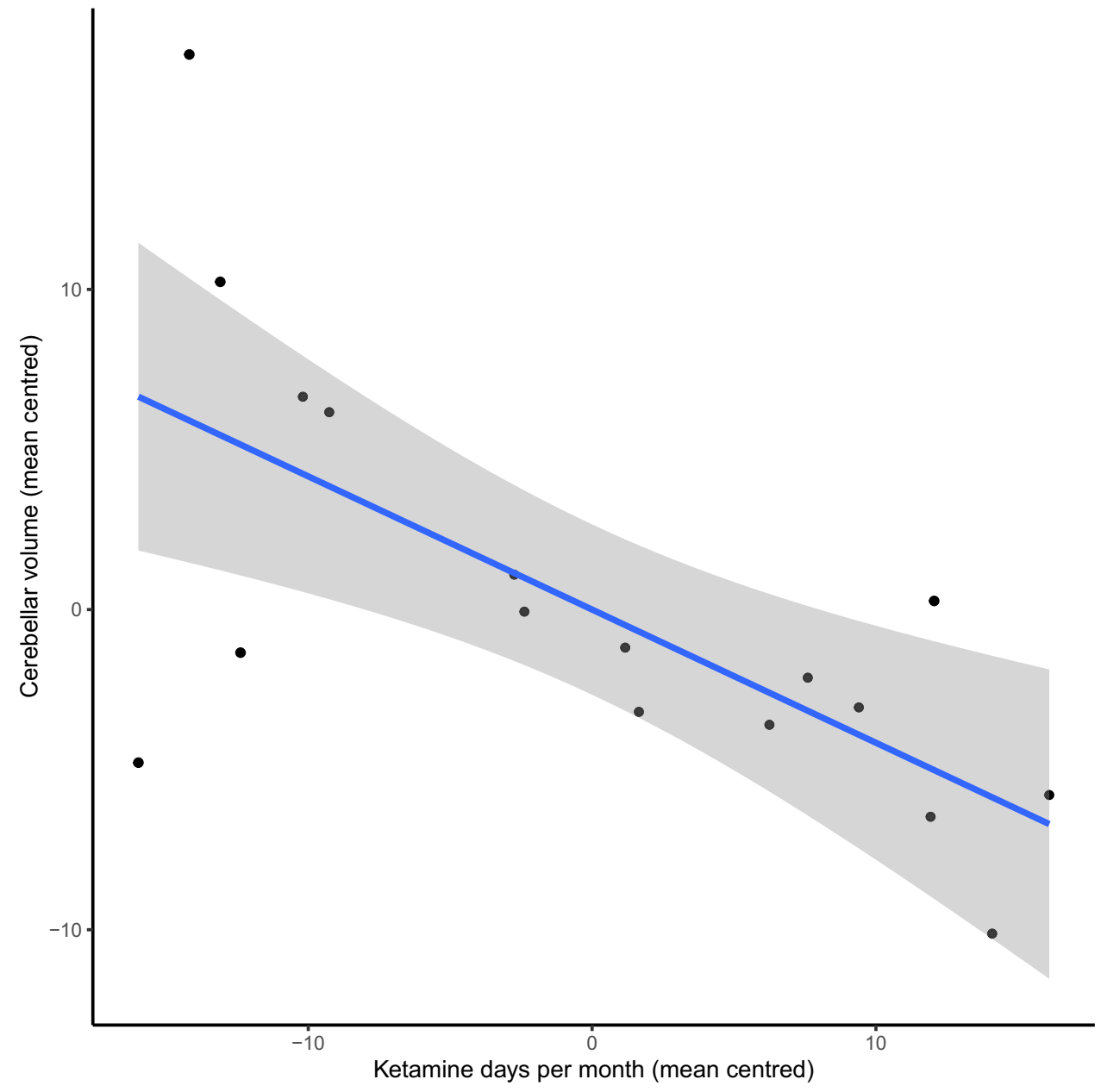

of reduced frontal (Liao et al. 2011) and parietal cortex grey matter volume in chronic ketamine users (Hung et al. 2020) as compared to healthy (i.e. non-poly-drug using) controls. They also match closely with the observations of grey matter reductions in the frontal, temporal and parietal cortices in patients with first episode psychosis and schizophrenia, reported by large-scale meta-analyses of such data (Brugger and Howes 2017; Vita et al. 2012). These findings are also in keeping with a recent mega-analysis of structural neuroimaging data in patients with schizophrenia which found global reductions in cortical surface area accompanied by reductions in frontal and temporal cortical thickness (van Erp et al. 2018).

We also found reduced volumes in caudate, nucleus accumbens and cerebellum in chronic ketamine users. One other group reported lesions in cerebellum and striatum in ketamine users (Wang et al. 2013), but these findings have not been reported in other studies. Another group found greater caudate volumes in poly-drug using ketamine users and pure ketamine users compared to non-drug using controls, as measured by MRI (Liang et al. 2020). The reason for this difference may be because we studied poly-drug users rather than non-drug users as controls. Alternatively, the differences may have arisen due to the heavier use of other drugs in the ketamine users in our study. In contrast, a group studying the effect of intermittent ketamine for treatment of major depressive disorder reported increases in grey matter volume in amygdala and hippocampus (Zhou et al. 2020). It is likely that the processes occurring when ketamine is used intermittently for the treatment of depression differ from chronic ketamine use in the setting of dependence or harmful use and may reflect the increases in dendritic spine formation that are hypothesised to underlie the antidepressant effects of ketamine, as supported by data from pre-clinical studies (Li et al. 2010).

It is interesting to note that the cerebellar volume reductions we found appear to occur in patients with schizophrenia (Moberget et al. 2018), but not those with bipolar affective disorder (Laidi et al. 2015), further strengthening the argument that chronic ketamine use may model some of the underlying neuropathology of schizophrenia. The largest meta-analysis of subcortical MRI studies in schizophrenia found reductions in the volume of the hippocampus as well as the amygdala, thalamus and nucleus accumbens (van Erp 
et al. 2016). This partially overlaps with our findings, but we did not see any reduction in either hippocampus or thalamus volumes in ketamine users in the present study.

As we reported in two previous overlapping studies (Morgan et al. 2014; Stone et al. 2014), we found increased sub-threshold psychotic symptoms in chronic ketamine users. These symptoms did not correlate with grey matter volume reductions. While correlations between grey matter volume and positive psychotic symptoms have previously been reported in patients with schizophrenia (Padmanabhan et al. 2015), the effect size was small ( $\mathrm{r}$ of approximately 0.15 ), requiring a sample of over 100 to detect a significant difference with a power of 0.8 . Thus, the present study was not of sufficient size to detect such a relationship and so further studies in larger samples are required to address this with sufficient power. The chronic ketamine users also had increased schizotypal personality symptoms as measured with the SPQ. It is not clear whether these features were longstanding or arose because of the regular ketamine use. Such information would require a longitudinal study and remains to be addressed.

One possible difficulty with using chronic ketamine use as a model to understand the underlying neurobiology of schizophrenia is that some of the chronic ketamine users may have had undeclared (or undiagnosed) schizophrenia. We attempted to address this possibility by recruiting patients who did not have any personal history of mental illness. Nonetheless, three of the ketamine users had symptomatology that reached diagnostic criteria for psychosis. This was not particularly surprising, given previous reports of schizophrenia-like symptomatology in chronic ketamine users (Abi-Saab et al. 1998; Javitt 2007; Jentsch and Roth 1999; Krystal et al. 1994; Morgan et al. 2012). To investigate the possibility that the findings were driven by these individuals, we ran post-hoc analyses from which they were excluded. Although there were fewer regions that were significantly different between controls and ketamine users in these analyses, the same overall finding of reduced grey matter volumes in the cerebellar cortex, nucleus accumbens and caudate nucleus and frontal, temporal and parietal cortical regions was seen. This shows that despite the reduced power due to excluding participants, the overall finding of reduced grey matter in chronic ketamine users compared to poly-drug using controls remained.

There are a number of limitations of the present study. (1) As mentioned, this study was relatively small, with low power to detect group differences, although this can also be attributed to the difficulty of recruiting poly-drug using controls and ketamine users. Future studies should aim, if possible, for a larger group size in order to address more subtle group differences; (2) despite our best efforts, the matching of the two groups was not perfect, with the ketamine users trending towards being older and having fewer years of education. Although these differences did not reach statistical significance, it is not clear to what extent this may have affected the results; (3) similarly, the ketamine and poly-drug users were not fully matched for their other drug use. We chose to match with a polydrug control group to try to take account of the effect of these drugs on the brain to tease out the effect of ketamine alone. However, ketamine users were more likely to also be users of MDMA, cocaine, amphetamine and heroin than the poly-drug users and were also heavier users of alcohol and cannabis, which is a particular challenge for studies of this type. This means that it is not possible to determine whether the lower brain volumes in ketamine users were primarily due to ketamine use or to the use of these other substances. Users of alcohol, amphetamines, cannabis, cocaine and opiates have shown similar reductions in frontal, parietal and temporal cortices, as well as in cerebellum (Batalla et al. 2013; Berman et al. 2008; Mackey and Paulus 2013; Syaifullah et al. 2020; Wollman et al. 2017). Indeed, it is striking how much overlap there is in regional reductions in grey matter volume with all these drugs of abuse, suggesting they may all have similar potential for toxicity to the brain (Mackey et al. 2019). Despite this, we found that the correlation between level of ketamine use and cerebellar volume was still present after correcting for the frequency of other drug use and that other drug use did not correlate with grey matter volume in any of the regions of interest, suggesting that at least some of the differences in brain grey matter between ketamine users and poly-drug using controls were due to ketamine use. Further controlled, reverse-translational studies on the effects of chronic NMDA antagonists in rodents may be of use to confirm (a) specific effects of ketamine and (b) link these to their cellular and molecular correlates postmortem (Doostdar et al. 2019).

In conclusion, this study shows that individuals with regular heavy ketamine use had lower grey matter volumes in cortical brain regions, cerebellum, nucleus accumbens and caudate nucleus, as indexed using structural MRI, compared to poly-drug using controls. These findings support the hypothesis that chronic ketamine use may lead to similar changes in grey matter that are seen in patients with first episode psychosis and schizophrenia, but caution is required given that other drugs of abuse with non-glutamatergic mechanisms of action lead to similar changes.

Supplementary Information The online version contains supplementary material available at https://doi.org/10.1007/s00213-021-05873-0.

Funding This work was supported by an MRC grant to Oliver Howes (grant code: MC_A656_5QD30). 


\section{Declarations}

Conflict of interest $\mathrm{OH}$ received investigator-initiated research funding from and/or participated in advisory/speaker meetings organised by AstraZeneca, Autifony, BMS, Eli Lilly, Heptares, Janssen, Lundbeck, Lyden-Delta, Otsuka, Servier, Sunovion, Rand and Roche. JMS received fees for consultancy work from Janssen Pharmaceutica and has been PI or sub-investigator on studies sponsored by Takeda, Janssen and Lundbeck Plc. He attended an Investigators' meeting run by Allergan Plc.

Open Access This article is licensed under a Creative Commons Attribution 4.0 International License, which permits use, sharing, adaptation, distribution and reproduction in any medium or format, as long as you give appropriate credit to the original author(s) and the source, provide a link to the Creative Commons licence, and indicate if changes were made. The images or other third party material in this article are included in the article's Creative Commons licence, unless indicated otherwise in a credit line to the material. If material is not included in the article's Creative Commons licence and your intended use is not permitted by statutory regulation or exceeds the permitted use, you will need to obtain permission directly from the copyright holder. To view a copy of this licence, visit http://creativecommons.org/licenses/by/4.0/.

\section{References}

Abi-Saab WM, D'Souza DC, Moghaddam B, Krystal JH (1998) The NMDA antagonist model for schizophrenia: promise and pitfalls. Pharmacopsychiatry 31(Suppl 2):104-109

Batalla A, Bhattacharyya S, Yucel M, Fusar-Poli P, Crippa JA, Nogue S, Torrens M, Pujol J, Farre M, Martin-Santos R (2013) Structural and functional imaging studies in chronic cannabis users: a systematic review of adolescent and adult findings. PLoS ONE 8:e55821

Berman S, O’Neill J, Fears S, Bartzokis G, London ED (2008) Abuse of amphetamines and structural abnormalities in the brain. Ann N Y Acad Sci 1141:195-220

Brugger SP, Howes OD (2017) Heterogeneity and homogeneity of regional brain structure in schizophrenia: a meta-analysis. JAMA Psychiat 74:1104-1111

Chung Y, Cannon TD (2015) Brain imaging during the transition from psychosis prodrome to schizophrenia. J Nerv Ment Dis 203:336-341

Corlett PR, Honey GD, Fletcher PC (2007) From prediction error to psychosis: ketamine as a pharmacological model of delusions. $\mathbf{J}$ Psychopharmacol 21:238-252

Desikan RS, Segonne F, Fischl B, Quinn BT, Dickerson BC, Blacker D, Buckner RL, Dale AM, Maguire RP, Hyman BT, Albert MS, Killiany RJ (2006) An automated labeling system for subdividing the human cerebral cortex on MRI scans into gyral based regions of interest. Neuroimage 31:968-980

Doostdar N, Kim E, Grayson B, Harte MK, Neill JC, Vernon AC (2019) Global brain volume reductions in a sub-chronic phencyclidine animal model for schizophrenia and their relationship to recognition memory. J Psychopharmacol 33:1274-1287

Freeman TP, Morgan CJ, Pepper F, Howes OD, Stone JM, Curran HV (2013) Associative blocking to reward-predicting cues is attenuated in ketamine users but can be modulated by images associated with drug use. Psychopharmacology 225:41-50

Humphries C, Mortimer A, Hirsch S, de Belleroche J (1996) NMDA receptor mRNA correlation with antemortem cognitive impairment in schizophrenia. NeuroReport 7:2051-2055
Hung CC, Liu YH, Huang CC, Chou CY, Chen CM, Duann JR, Li CR, Lee TS, Lin CP (2020) Effects of early ketamine exposure on cerebral gray matter volume and functional connectivity. Sci Rep 10:15488

Javitt DC (2007) Glutamate and schizophrenia: phencyclidine, $\mathrm{N}$-methyl-D-aspartate receptors, and dopamine-glutamate interactions. Int Rev Neurobiol 78:69-108

Jentsch JD, Roth RH (1999) The neuropsychopharmacology of phencyclidine: from NMDA receptor hypofunction to the dopamine hypothesis of schizophrenia. Neuropsychopharmacology 20:201-225

Krystal JH, Karper LP, Seibyl JP, Freeman GK, Delaney R, Bremner JD, Heninger GR, Bowers MB Jr, Charney DS (1994) Subanesthetic effects of the noncompetitive NMDA antagonist, ketamine, in humans. Psychotomimetic, perceptual, cognitive, and neuroendocrine responses. Arch Gen Psychiatry 51:199-214

Lahti AC, Weiler MA, Tamara Michaelidis BA, Parwani A, Tamminga CA (2001) Effects of ketamine in normal and schizophrenic volunteers. Neuropsychopharmacology 25:455-467

Laidi C, d'Albis MA, Wessa M, Linke J, Phillips ML, Delavest M, Bellivier F, Versace A, Almeida J, Sarrazin S, Poupon C, Le Dudal K, Daban C, Hamdani N, Leboyer M, Houenou J (2015) Cerebellar volume in schizophrenia and bipolar I disorder with and without psychotic features. Acta Psychiatr Scand 131:223-233

Law AJ, Deakin JF (2001) Asymmetrical reductions of hippocampal NMDAR1 glutamate receptor mRNA in the psychoses. NeuroReport 12:2971-2974

Li N, Lee B, Liu RJ, Banasr M, Dwyer JM, Iwata M, Li XY, Aghajanian G, Duman RS (2010) mTOR-dependent synapse formation underlies the rapid antidepressant effects of NMDA antagonists. Science 329:959-964

Liang H, Tang WK, Chu WCW, Ernst T, Chen R, Chang L (2020) Striatal and white matter volumes in chronic ketamine users with or without recent regular stimulant use. Drug Alcohol Depend 213:108063

Liao Y, Tang J, Corlett PR, Wang X, Yang M, Chen H, Liu T, Chen X, Hao W, Fletcher PC (2011) Reduced dorsal prefrontal gray matter after chronic ketamine use. Biol Psychiatry 69:42-48

Mackey S, Allgaier N, Chaarani B, Spechler P, Orr C, Bunn J, Allen NB, Alia-Klein N, Batalla A, Blaine S, Brooks S, Caparelli E, Chye YY, Cousijn J, Dagher A, Desrivieres S, Feldstein-Ewing S, Foxe JJ, Goldstein RZ, Goudriaan AE, Heitzeg MM, Hester R, Hutchison K, Korucuoglu O, Li CR, London E, Lorenzetti V, Luijten M, Martin-Santos R, May A, Momenan R, Morales A, Paulus MP, Pearlson G, Rousseau ME, Salmeron BJ, Schluter R, Schmaal L, Schumann G, Sjoerds Z, Stein DJ, Stein EA, Sinha R, Solowij N, Tapert S, Uhlmann A, Veltman D, van Holst R, Whittle S, Wright MJ, Yucel M, Zhang S, Yurgelun-Todd D, Hibar DP, Jahanshad N, Evans A, Thompson PM, Glahn DC, Conrod P, Garavan H, Group EAW (2019) Mega-analysis of gray matter volume in substance dependence: general and substance-specific regional effects. Am J Psychiatry 176:119-128

Mackey S, Paulus M (2013) Are there volumetric brain differences associated with the use of cocaine and amphetamine-type stimulants? Neurosci Biobehav Rev 37:300-316

Malhotra AK, Pinals DA, Adler CM, Elman I, Clifton A, Pickar D, Breier A (1997) Ketamine-induced exacerbation of psychotic symptoms and cognitive impairment in neuroleptic-free schizophrenics. Neuropsychopharmacology 17:141-150

Moberget T, Doan NT, Alnaes D, Kaufmann T, Cordova-Palomera A, Lagerberg TV, Diedrichsen J, Schwarz E, Zink M, Eisenacher S, Kirsch P, Jonsson EG, Fatouros-Bergman H, Flyckt L, KaSp PG, Quarto T, Bertolino A, Barch D, Meyer-Lindenberg A, Agartz I, Andreassen OA, Westlye LT (2018) Cerebellar volume and cerebellocerebral structural covariance in schizophrenia: a multisite 
mega-analysis of 983 patients and 1349 healthy controls. Mol Psychiatry 23:1512-1520

Morgan CJ, Curran HV, Independent scientific committee on D (2012) ketamine use: a review. Addiction 107:27-38

Morgan CJ, Dodds CM, Furby H, Pepper F, Fam J, Freeman TP, Hughes E, Doeller C, King J, Howes O, Stone JM (2014) Longterm heavy ketamine use is associated with spatial memory impairment and altered hippocampal activation. Front Psychiatry 5:149

Olney JW, Farber NB (1995) Glutamate receptor dysfunction and schizophrenia. Arch Gen Psychiatry 52:998-1007

Padmanabhan JL, Tandon N, Haller CS, Mathew IT, Eack SM, Clementz BA, Pearlson GD, Sweeney JA, Tamminga CA, Keshavan MS (2015) Correlations between brain structure and symptom dimensions of psychosis in schizophrenia, schizoaffective, and psychotic bipolar I disorders. Schizophr Bull 41:154-162

Pilowsky LS, Bressan RA, Stone JM, Erlandsson K, Mulligan RS, Krystal JH, Ell PJ (2006) First in vivo evidence of an NMDA receptor deficit in medication-free schizophrenic patients. Mol Psychiatry 11:118-119

Raine A (1991) The SPQ: a scale for the assessment of schizotypal personality based on DSM-III-R criteria. Schizophr Bull 17:555-564

Sokolov BP (1998) Expression of NMDAR1, GluR1, GluR7, and KA1 glutamate receptor mRNAs is decreased in frontal cortex of "neuroleptic-free" schizophrenics: evidence on reversible upregulation by typical neuroleptics. J Neurochem 71:2454-2464

Stone JM, Pepper F, Fam J, Furby H, Hughes E, Morgan C, Howes OD (2014) Glutamate, N-acetyl aspartate and psychotic symptoms in chronic ketamine users. Psychopharmacology 231:2107-2116

Syaifullah AH, Shiino A, Fujiyoshi A, Kadota A, Kondo K, Ito T, Segawa H, Moniruzzaman M, Waki T, Miyagawa N, Tooyama I, Ueshima H, Miura K, SRGroup, Co c, Ueshima H, Miura K, Research m (2020) Alcohol drinking and brain morphometry in apparently healthy community-dwelling Japanese men. Alcohol 90:57-65

van Erp TG, Hibar DP, Rasmussen JM, Glahn DC, Pearlson GD, Andreassen OA, Agartz I, Westlye LT, Haukvik UK, Dale AM, Melle I, Hartberg CB, Gruber O, Kraemer B, Zilles D, Donohoe G, Kelly S, McDonald C, Morris DW, Cannon DM, Corvin A, Machielsen MW, Koenders L, de Haan L, Veltman DJ, Satterthwaite TD, Wolf DH, Gur RC, Gur RE, Potkin SG, Mathalon DH, Mueller BA, Preda A, Macciardi F, Ehrlich S, Walton E, Hass J, Calhoun VD, Bockholt HJ, Sponheim SR, Shoemaker JM, van Haren NE, Hulshoff Pol HE, Ophoff RA, Kahn RS, RoizSantianez R, Crespo-Facorro B, Wang L, Alpert KI, Jonsson EG, Dimitrova R, Bois C, Whalley HC, McIntosh AM, Lawrie SM, Hashimoto R, Thompson PM, Turner JA (2016) Subcortical brain volume abnormalities in 2028 individuals with schizophrenia and 2540 healthy controls via the ENIGMA consortium. Mol Psychiatry 21:547-553

van Erp TGM, Walton E, Hibar DP, Schmaal L, Jiang W, Glahn DC, Pearlson GD, Yao N, Fukunaga M, Hashimoto R, Okada N, Yamamori H, Bustillo JR, Clark VP, Agartz I, Mueller BA, Cahn W, de Zwarte SMC, Hulshoff Pol HE, Kahn RS, Ophoff RA, van Haren NEM, Andreassen OA, Dale AM, Doan NT, Gurholt TP, Hartberg CB, Haukvik UK, Jorgensen KN, Lagerberg TV, Melle I, Westlye LT, Gruber O, Kraemer B, Richter A, Zilles D, Calhoun
VD, Crespo-Facorro B, Roiz-Santianez R, Tordesillas-Gutierrez D, Loughland C, Carr VJ, Catts S, Cropley VL, Fullerton JM, Green MJ, Henskens FA, Jablensky A, Lenroot RK, Mowry BJ, Michie PT, Pantelis C, Quide Y, Schall U, Scott RJ, Cairns MJ, Seal M, Tooney PA, Rasser PE, Cooper G, Shannon Weickert C, Weickert TW, Morris DW, Hong E, Kochunov P, Beard LM, Gur RE, Gur RC, Satterthwaite TD, Wolf DH, Belger A, Brown GG, Ford JM, Macciardi F, Mathalon DH, O'Leary DS, Potkin SG, Preda A, Voyvodic J, Lim KO, McEwen S, Yang F, Tan Y, Tan S, Wang Z, Fan F, Chen J, Xiang H, Tang S, Guo H, Wan P, Wei D, Bockholt HJ, Ehrlich S, Wolthusen RPF, King MD, Shoemaker JM, Sponheim SR, De Haan L, Koenders L, Machielsen MW, van Amelsvoort T, Veltman DJ, Assogna F, Banaj N, de Rossi P, Iorio M, Piras F, Spalletta G, McKenna PJ, Pomarol-Clotet E, Salvador R, Corvin A, Donohoe G, Kelly S, Whelan CD, Dickie EW, Rotenberg D, Voineskos AN, Ciufolini S, Radua J, Dazzan P, Murray R, Reis Marques T, Simmons A, Borgwardt S, Egloff L, Harrisberger F, Riecher-Rossler A, Smieskova R, Alpert KI, Wang L, Jonsson EG, Koops S, Sommer IEC, Bertolino A, Bonvino A, Di Giorgio A, Neilson E, Mayer AR, Stephen JM, Kwon JS, Yun JY, Cannon DM, McDonald C, Lebedeva I, Tomyshev AS, Akhadov T, Kaleda V, Fatouros-Bergman H, Flyckt L, Karolinska Schizophrenia P, Busatto GF, Rosa PGP, Serpa MH, Zanetti MV, Hoschl C, Skoch A, Spaniel F, Tomecek D, Hagenaars SP, McIntosh AM, Whalley HC, Lawrie SM, Knochel C, Oertel-Knochel V, Stablein M, Howells FM, Stein DJ, Temmingh HS, Uhlmann A, Lopez-Jaramillo C, Dima D, McMahon A, Faskowitz JI, Gutman BA, Jahanshad N, Thompson PM, Turner JA (2018) Cortical brain abnormalities in 4474 individuals with schizophrenia and 5098 control subjects via the enhancing neuro imaging genetics through meta analysis (ENIGMA) consortium. Biol Psychiatry 84:644-654

Vita A, De Peri L, Deste G, Sacchetti E (2012) Progressive loss of cortical gray matter in schizophrenia: a meta-analysis and metaregression of longitudinal MRI studies. Transl Psychiatry 2:e190

Wang C, Zheng D, Xu J, Lam W, Yew DT (2013) Brain damages in ketamine addicts as revealed by magnetic resonance imaging. Front Neuroanat 7:23

Wollman SC, Alhassoon OM, Hall MG, Stern MJ, Connors EJ, Kimmel CL, Allen KE, Stephan RA, Radua J (2017) Gray matter abnormalities in opioid-dependent patients: a neuroimaging metaanalysis. Am J Drug Alcohol Abuse 43:505-517

Yung AR, Yuen HP, McGorry PD, Phillips LJ, Kelly D, Dell'Olio M, Francey SM, Cosgrave EM, Killackey E, Stanford C, Godfrey K, Buckby J (2005) Mapping the onset of psychosis: the Comprehensive Assessment of At-Risk Mental States. Aust N Z J Psychiatry 39:964-971

Zhou YL, Wu FC, Liu WJ, Zheng W, Wang CY, Zhan YN, Lan XF, Ning YP (2020) Volumetric changes in subcortical structures following repeated ketamine treatment in patients with major depressive disorder: a longitudinal analysis. Transl Psychiatry 10:264

Publisher's note Springer Nature remains neutral with regard to jurisdictional claims in published maps and institutional affiliations. 